2014s-20

\title{
Curbing Emissions through a Carbon Liabilities Market: A note from a climate skeptic's perspective
}

Etienne Billette de Villemeur, Justin Leroux

\section{Série Scientifique \\ Scientific Series}

\author{
Montréal \\ Février 2014/February 2014
}

(C) 2014 Etienne Billette de Villemeur, Justin Leroux. Tous droits réservés. All rights reserved. Reproduction partielle permise avec citation du document source, incluant la notice (C).

Short sections may be quoted without explicit permission, if full credit, including (C) notice, is given to the source.
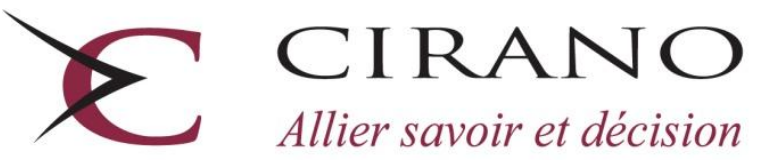

Allier savoir et décision

Centre interuniversitaire de recherche en analyse des organisations 


\section{CIRANO}

Le CIRANO est un organisme sans but lucratif constitué en vertu de la Loi des compagnies du Québec. Le financement de son infrastructure et de ses activités de recherche provient des cotisations de ses organisations-membres, d'une subvention d'infrastructure du Ministère de l'Enseignement supérieur, de la Recherche, de la Science et de la Technologie, de même que des subventions et mandats obtenus par ses équipes de recherche.

CIRANO is a private non-profit organization incorporated under the Québec Companies Act. Its infrastructure and research activities are funded through fees paid by member organizations, an infrastructure grant from the Ministère de l'Enseignement supérieur, de la Recherche, de la Science et de la Technologie, and grants and research mandates obtained by its research teams.

\section{Les partenaires du CIRANO}

\section{Partenaire majeur}

Ministère de l'Enseignement supérieur, de la Recherche, de la Science et de la Technologie

\section{Partenaires corporatifs}

Autorité des marchés financiers

Banque de développement du Canada

Banque du Canada

Banque Laurentienne du Canada

Banque Nationale du Canada

Banque Scotia

Bell Canada

BMO Groupe financier

Caisse de dépôt et placement du Québec

Fédération des caisses Desjardins du Québec

Financière Sun Life, Québec

\section{Gaz Métro}

Hydro-Québec

Industrie Canada

Investissements PSP

Ministère des Finances et de l'Économie

Power Corporation du Canada

Rio Tinto Alcan

Transat A.T.

Ville de Montréal

\section{Partenaires universitaires}

École Polytechnique de Montréal

École de technologie supérieure (ÉTS)

HEC Montréal

Institut national de la recherche scientifique (INRS)

McGill University

Université Concordia

Université de Montréal

Université de Sherbrooke

Université du Québec

Université du Québec à Montréal

Université Laval

Le CIRANO collabore avec de nombreux centres et chaires de recherche universitaires dont on peut consulter la liste sur son site web.

Les cahiers de la série scientifique (CS) visent à rendre accessibles des résultats de recherche effectuée au CIRANO afin de susciter échanges et commentaires. Ces cahiers sont écrits dans le style des publications scientifiques. Les idées et les opinions émises sont sous l'unique responsabilité des auteurs et ne représentent pas nécessairement les positions du CIRANO ou de ses partenaires.

This paper presents research carried out at CIRANO and aims at encouraging discussion and comment. The observations and viewpoints expressed are the sole responsibility of the authors. They do not necessarily represent positions of CIRANO or its partners. 


\title{
Curbing Emissions through a Carbon Liabilities Market: A note from a climate skeptic's perspective *
}

\author{
Etienne Billette de Villemeur ${ }^{*}$, Justin Leroux ${ }^{*}$
}

\begin{abstract}
Résumé/abstract
We argue for the creation of a carbon liabilities market to address climate change. Each period, countries would be made liable for their share of responsibility in current climate damage. Because liabilities could be traded like financial debt, robustness to strategic manipulations and efficiency ensue. Moreover, this decentralizes the choice of the rate by which countries discount future benefits and damage. Rather than being based on an expected discounted sum of future marginal damage (as with a carbon tax or tradable emission permits) our proposal relies only on observed realized damage and on the well-documented emission history of countries.
\end{abstract}

Mots clés/Keywords: Carbon Liabilities, Climate Policy, Market Instruments.

Codes JEL : Q54, H23.

\footnotetext{
"The authors wish to thank Geir Asheim, Hassan Benchekroun, Yann Bramoullé, Alessio D.Amato, Georges Dionne, Paul Ekins, Gérard Gaudet, André Grimaud, Christian Gollier, Jérémy Laurent-Luchetti, Peter Hartley, Marcus Hermann, Louis Hotte, Shi-Ling Hsu, Yann Kervinio, Stéphane Lambrecht, Derek Lemoine, Leslie Martin, Stephen Salant, Marc Santugini, Charles Séguin, Jens Steffek, Nicolas Treich, Edilio Valentini, Bruno Versaevel, Mirko Wiederholt, Ralph Winkler as well as participants of the 2012 Occasional California Workshop on Environmental and Resource Economics, the Montreal Resource and Environmental Economics Workshop, and the 2012 Paris Environmental and Energy Economics Seminar (PEEES).

†EQUIPPE, Université de Lille, France.

${ }^{\ddagger}$ HEC Montréal, CIRANO \& CIRPEE, Canada, justin.leroux@hec.ca.
} 


\section{Introduction}

Climate policies that rely on economic instruments, such as emissions taxes or cap-and-trade programs, exact immediate payments on the basis that climate damage will occur in the future. In principle, an optimal carbon tax asks emitters to pay today the expected discounted marginal damage of emissions, according to some climate damage scenarios - over the next decades, sometimes centuries - that may or may not materialize. Likewise, the number of tradable permits issued in an efficient cap-and-trade programs is also contingent on said scenarios, effectively costing emitters the full expected consequences of their emissions flows upon emitting. Should these scenarios or mankind's responsibility in them prove inaccurate, such anticipatory schemes would cause needless disruptions to the economy.

Instead, we argue in favor of holding countries liable for climate damage arising from their greenhouse gas emissions through the creation of a market for liabilities. Concretely, emitting $\mathrm{CO}_{2}$ in the atmosphere ${ }^{1}$ would be accompanied by the issuance of a carbon liability: a legal duty for the bearer to pay damages over time as climate damage occurs. ${ }^{2}$ In other words, the bearers of carbon liabilities would be repaying their debt to the world in installments rather than upfront. Carbon liabilities would not expire, but would instead decay at the same rate as atmospheric $\mathrm{CO}_{2}$, all the while holding its bearers accountable for paying carbon damages as climate damage occurs. Carbon liabilities could be sold to other countries, by paying them to honor their newly acquired responsibility in future climate damage. ${ }^{3}$ Free trade on the global market would ensure efficiency.

The idea of using liabilities as a means to controlling externalities traces back

\footnotetext{
${ }^{1}$ For expositional purposes, we shall speak only in terms of $\mathrm{CO}_{2}$.

${ }^{2}$ Clearly, the issue of determining the magnitude of anthropogenic climate damage is a difficult one. Note, however, that this question is by no means resolved with a carbon tax. In fact it is made even worse, because estimating the value of the damage caused by a ton of carbon emitted today decades or centuries into the future is a much more heroic feat than assessing the responsibility of past emissions in (observed) damage ocurring today. Yet, very few objections to the carbon tax seem to be raised on those grounds.

${ }^{3}$ Thanks to the financiarisation of climate liabilities, carbon damages would add to the national debt. Therefore, there is no reason to be more concerned by countries defaulting on the payment of carbon damages than by their defaulting on the repayment of national debt.

However, there is a difference in the nature of these debts. In the unlikely case of default on financial debt, those affected are creditors who chose to expose themselves to financial risk. By contrast, those affected by default on carbon debt are likely to be residents of vulnerable countries that did not choose to expose themselves to climate risk. We thank Yann Kervinio for this observation.
} 
to Calabresi (1970) and was recently compared to corrective taxation in Shavell (2011). On the one hand, regulation (taxation) is costly even in the absence of damage, whereas a liability approach only kicks in when harm actually occurs. On the other hand, a liability approach is typically more informationally demanding because it requires establishing tort (Kolstad et al, 1990; Shavell, 2011). Hence, a liability approach is likely to be more appropriate in situations where damage is highly uncertain but where its source can be easily established. This is precisely the case of climate change, where the magnitude of damage is typically unknown but the responsibility of countries towards $\mathrm{CO}_{2}$ concentration can be readily established thanks to available data on cumulated $\mathrm{CO}_{2}$ emissions per country (e.g., from the World Resource Institute or the World Bank databases). ${ }^{4}$

\section{Efficiency}

Let $\left\{D_{t}\right\}_{t=0}^{+\infty}=\left\{\sum_{i} D_{t}^{i}\right\}_{t=0}^{+\infty}$ denote the flow of stochastic damage borne by all countries, indexed by $i$, as attached to anthropogenic climate change. At any period $t$, the occurrence and the magnitude of this damage is assumed to be an increasing function of $Z_{t}$, the current stock of anthropogenic $\mathrm{CO}_{2}$ in the atmosphere. Our proposal consists in converting $\mathrm{CO}_{2}$ emissions into financial debt. More precisely, in each period, all countries are required to contribute to an international climate fund to the tune of $\mu_{t} Z_{t}^{j}$ where $\mu_{t}=d D_{t} / d Z_{t}$ is the marginal climate damage due to anthropogenic emissions ${ }^{5}$ and where $Z_{t}^{j}=$ $\sum_{s=-\infty}^{t} \gamma^{s} X_{s}^{j}$ is the contribution of country $j$ to the stock $Z_{t}$ (it is the discounted sum of its past emissions $X_{s}^{j}$, for all $s \leq t$, accounting for their natural decay at rate $1-\gamma){ }^{6}$

\footnotetext{
${ }^{4}$ The liability approach is usually discussed in the context of tort law, involving private parties and legal costs attached to lawsuits, to establishing due care and negligence. By contrast, the liability approach we consider here is public, in the sense that it involves countries, and would consist in an automatic procedure where the negligence rule plays no role. Countries would be held responsible for climate damage according to their past emissions.

${ }^{5}$ Unlike in tort law, we do not aim for "full liability" because it is not optimal to cover all the costs. Rather, we require countries to pay for the marginal damage they induce, hence our use of the phrase "efficient carbon liabilities".

${ }^{6}$ It is actually not required to trace back emissions to infinity. In fact, accounting only for, say, post-1990 emissions would result in the very same emissions pattern. Indeed, the truncation simply amounts to lump-sum transfers to countries while preserving incentives at the margin.
} 
Proposition 1 Under the usual Pigovian assumptions that no single agent has an impact on the marginal damage, ${ }^{7}$ such a carbon debt scheme yields first-best emission patterns.

Proof. Under rational expectations, country $i$ evaluates its present net benefit as:

$$
B^{i}=\sum_{t=0}^{+\infty} \beta^{t}\left[B_{t}^{i}\left(X_{t}^{i}\right)-\mu_{t} Z_{t}^{i}\right]
$$

where $B_{t}^{i}\left(X_{t}^{i}\right)$ is the per-period benefit of country $i$ resulting from its emissions in the current period. Country $i$ then chooses an emissions stream $\left\{X_{t}^{i}\right\}_{t=0}^{+\infty}$ such that:

$$
\frac{\partial B_{t}^{i}}{\partial X_{t}^{i}}=E_{t}\left[\sum_{s=t}^{+\infty} \beta^{s-t} \mu_{s} \frac{\partial Z_{s}^{i}}{\partial X_{t}^{i}}\right]=E_{t}\left[\sum_{s=t}^{+\infty}(\gamma \beta)^{s-t} \frac{\partial D_{s}}{\partial Z_{s}}\right]
$$

under the assumption that no single agent has an impact on marginal damage. Each country equalizes its marginal benefit with the expected discounted value of marginal climate damage, thus achieving first-best efficiency.

Notice that the only information required of the planner to implement our scheme, on top of the well-documented emission history of countries, is $\mu_{t}=\frac{d D_{t}}{d Z_{t}}$ : the marginal impact of current anthropogenic $\mathrm{CO}_{2}$ concentration on the current flow of climate damage. While obtaining this information accurately may be no small task, it seems far less daunting to be working with observed data than with predictions over future decades or centuries. Indeed, the information required to implement an efficient carbon tax, $\tau$, or the equivalent cap-and-trade program is the expected, discounted sum of the marginal impacts of current emissions on future climate damage:

$$
\tau_{t}=E_{t}\left[\sum_{s=t}^{+\infty} \beta^{s-t} \frac{\partial Z_{s}^{i}}{\partial X_{t}^{i}} \frac{\partial D_{s}}{\partial Z_{s}}\right]=E_{t}\left[\sum_{s=t}^{+\infty}(\gamma \beta)^{s-t} \frac{\partial D_{s}}{\partial Z_{s}}\right] .
$$

From a policy standpoint, implementing our carbon debt policy is simpler than implementing a cap-and-trade program. Under our scheme, carbon debt is issued and allocated systematically based on each country's observed emissions.

\footnotetext{
${ }^{7}$ We shall work under this assumption throughout. It follows that we shall ignore strategic issues associated with the relative size of countries as discussed in the next section.
} 
By contrast, cap-and-trade schemes require a planner to issue and allocate permits with the obvious risks of miscalculation and misallocation, respectively.

The upshot of requiring less of the planner is that much more freedom is left to the countries, thus allowing for more decentralization than, say, a harmonized carbon tax policy or a global cap-and-trade program. ${ }^{8}$ Specifically, countries make their own predictions about future damage and work with their own discount factors. However, there is a limit to decentralization: making firms liable would increase default risk and lead to skewed incentives. By contrast, assigning liabilities at the country level ensures solvability and correct incentives because nations are long-lived. In addition, this gives countries sovereignty on how to finance their carbon damages.

Section 3 addresses how trade can maintain efficiency in the case where countries have different discount factors and different expectations about future anthropogenic climate damage.

\section{Robustness}

If debt can be traded, our approach is robust to heterogeneity in discount factors and to diverging forecasts. If discount factors and forecasts are country-specific Expression (2) becomes:

$$
\frac{\partial B_{t}^{i}}{\partial X_{t}^{i}}=E_{t}^{i}\left[\sum_{s=t}^{+\infty}\left(\gamma \beta_{i}\right)^{s-t} \mu_{s}\right]
$$

where $\beta_{i}$ and $E_{t}^{i}$ are the discount factor and the expectations of country $i$, respectively.

Country heterogeneity yields trade opportunities: a market for debt leaves it to countries to determine how much debt they wish to hold based on their predictions of future climate change damage. Should opinions differ on the likelihood and magnitude of future damage, or on the discount rate, efficiency is maintained through trade as we now show.

Specifically, given a competitive market price, $p_{t}$, countries may choose to buy carbon debt - and be paid to do so - or to sell them, by paying others to

\footnotetext{
${ }^{8}$ Setting a number of permits is tantamount to choosing a discount factor and to adopting a specific prediction of future climate damage. Thus, from this perspective, a global capand-trade program is actually closer to centralization than to decentralization (even though efficiency calls against the fragmentation of permit markets).
} 
hold debt in their stead.

Proposition 2 Consider a carbon liabilities scheme where installments are set to current marginal climate damage: $\mu_{t}=\frac{\partial D_{t}}{\partial Z_{t}}$. Allowing carbon debt to be traded maintains efficiency while decentralizing preferences and beliefs.

Proof. We show that efficiency is robust to heterogeneity in countries' discount factors. The proof assuming countries formulate different expectations about future damage, $E_{t}^{i}$, proceeds similarly.

Suppose countries have heterogeneous discount factors. Assume country $j$ sells $Y_{t}^{j}$ units of the debt associated to its current emissons, $X_{t}^{j}+Y_{t}^{j}$. Its expected net present benefit writes as follows:

$$
B^{j}=\sum_{t=0}^{+\infty} \beta_{j}^{t} E_{0}\left[B_{t}^{j}\left(X_{t}^{j}+Y_{t}^{j}\right)-p_{t} Y_{t}^{j}-\left[\mu_{t} Z_{t}^{j}+c_{t}^{j}\left(p_{t} Z_{t}^{j}\right)\right]\right]
$$

where $c_{t}^{j}$ is the cost of holding financial debt for country $j$ at date $t$ and

$$
Z_{t}^{j}=\gamma Z_{t-1}^{j}+X_{t}^{j}
$$

is the amount of carbon debt held by country $j$ at date $t$. The sole purpose of introducing a cost of holding financial debt is to ensure an interior solution. We interpret it as country default risk and therefore assume it to be negligible for usual levels of debt. We assume $c_{t}^{j}$ to be increasing, strictly convex, and such that $c_{t}^{j}(0)=0$.

Similarly, assume country $i$ purchases $Y_{t}^{i}$ units of debt, as measured in carbon stock units. Its expected net present benefit writes as follows:

$$
B^{i}=\sum_{t=0}^{+\infty} \beta_{i}^{t} E_{0}\left[B_{t}^{i}\left(X_{t}^{i}\right)+p_{t} Y_{t}^{i}-\left[\mu_{t} Z_{t}^{i}+c_{t}^{i}\left(p_{t} Z_{t}^{i}\right)\right]\right]
$$

where the carbon stock for which country $i$ is considered to be responsible now writes:

$$
Z_{t}^{i}=\gamma Z_{t-1}^{i}+X_{t}^{i}+Y_{t}^{i}
$$

From the point of view of a net seller of carbon debt, the first-order conditions 
write as follows:

$$
\begin{aligned}
\frac{\partial B_{t}^{j}}{\partial X_{t}^{j}} & =E_{t}\left[\sum_{s=t}^{+\infty} \beta_{j}^{s-t} \frac{\partial Z_{s}^{j}}{\partial X_{t}^{j}}\left[\mu_{s}+p_{s} c^{j}\left(p_{s} Z_{s}^{i}\right)\right]\right] \\
& =E_{t}\left[\sum_{s=t}^{+\infty}\left(\gamma \beta_{j}\right)^{s-t}\left[\frac{\partial D_{s}}{\partial Z_{s}}+p_{s} c^{\prime j}\left(p_{s} Z_{s}^{j}\right)\right]\right] \\
\frac{\partial B_{t}^{j}}{\partial Y_{t}^{j}} & =p_{t}
\end{aligned}
$$

From the point of view of a net buyer of carbon debt, the first-order conditions are the following:

$$
\begin{aligned}
\frac{\partial B_{t}^{i}}{\partial X_{t}^{i}} & =E_{t}\left[\sum_{s=t}^{+\infty} \beta_{i}^{s-t} \frac{\partial Z_{s}^{i}}{\partial X_{t}^{i}}\left[\mu_{s}+p_{s} c^{i}\left(p_{s} Z_{s}^{i}\right)\right]\right] \\
& =E_{t}\left[\sum_{s=t}^{+\infty}\left(\gamma \beta_{i}\right)^{s-t}\left[\frac{\partial D_{s}}{\partial Z_{s}}+p_{s} c^{i}\left(p_{s} Z_{s}^{i}\right)\right]\right] \\
p_{t} & =E_{t}\left[\sum_{s=t}^{+\infty} \beta_{i}^{s-t} \frac{\partial Z_{s}^{i}}{\partial Y_{t}^{i}}\left[\mu_{s}+p_{s} c^{\prime i}\left(p_{s} Z_{s}^{i}\right)\right]\right] \\
& =E_{t}\left[\sum_{s=t}^{+\infty}\left(\gamma \beta_{i}\right)^{s-t}\left[\frac{\partial D_{s}}{\partial Z_{s}}+p_{s} c^{\prime i}\left(p_{s} Z_{s}^{i}\right)\right]\right]
\end{aligned}
$$

It follows that, for all $i$ :

$$
\frac{\partial B_{t}^{i}}{\partial X_{t}^{i}}=p_{t}
$$

and for all $j$

$$
p_{t}=\frac{\partial B_{t}^{j}}{\partial Y_{t}^{j}}=\frac{\partial B_{t}^{j}}{\partial X_{t}^{j}}
$$

yielding efficiency

Proposition 2 can be seen as an analog of the First Welfare Theorem, whereby allowing carbon debt to be traded yields allocative efficiency through decentralization. ${ }^{9}$ Furthemore, another consequence of Proposition 2 is that our scheme allows for diverging opinions regarding climate change. It is also noteworthy that our mechanism is robust in the sense of being immune to strategic ma-

\footnotetext{
${ }^{9}$ It would be interesting to explore whether an equivalent of the Second Welfare Theorem holds. For an attempt to conjugate allocative efficiency with the redistributive aspects of global warming, see Billette de Villemeur and Leroux (2011).
} 
nipulation both in the discount factor and in the expectations because the final allocation of debt is a competitive market outcome. To sum up, the introduction of a market for carbon debt makes our mechanism robust to misrepresentation and to misreporting.

Morever:

Remark 3 Because our scheme financializes the carbon debt, failure to honor the latter is now no different than a default in the repayment of financial debt.

If countries take part in this scheme, they are unlikely to renege on their participation. Naturally, there is the question of whether countries will participate in the first place, leading to the general theme of coalition formation in international environmental agreements. Because the expected net discounted payoffs of countries are identical under our approach as with an optimal carbon tax, we do not expect to obtain in our setting markedly different conclusions from those of that litterature. Of course, those very important questions deserve to be addressed more carefully, which we leave to future work.

\section{$4 \quad$ Liability}

Although there is some evidence that climate change already has an impact on economic outcomes, climate damage remains highly uncertain and volatile. It follows that ex ante approaches to climate policy exhibit the unappealing feature of possibly requiring high payments when realized damage is low. A liability approach avoid this disconnectedness by linking payments to realized harm. ${ }^{10}$

The key feature of our mechanism is that the prospect of being liable for future damage creates incentives to reduce emissions today. It is a general principle of justice that no party can be liable in the absence of "constructive notice". ${ }^{11}$ In other words, a country should not be asked to pay for the climate consequences of emissions made before the discovery of the impact of greenhouse gases on the climate. As already mentioned, however, our mechanism does not require tracing back emissions to infinity, but can account for anthropogenic

\footnotetext{
${ }^{10}$ In tort law, one aspect of the debate between the regulatory and the liability approaches we did not yet mention is the fact that payments reflect realized harm in the latter whereas they are based on the possibility of harm in the former. On this, see Shavell $(1984,2011)$ and Kolstad et al (1990).

${ }^{11}$ We thank Shi-Ling Hsu for bringing this issue to our attention.
} 
emissions starting at some agreed-upon reference date only. It thus does not violate this basic legal principle. ${ }^{12}$

Because it requires a consensus only on the principle and on a starting date, one can expect an agreement to be more easily reached with a liability approach than with taxation. Indeed, the latter requires a consensus on the magnitude of yet unrealized climate events far off in the future, a much more ambitious goal.

We now turn to a formal presentation of our liability scheme. Assume that payments are adjusted according to realized damage, $D\left(Z_{t}\right)$. More precisely, assume that countries are actually required to pay $\mu_{t} Z_{t}^{i} \mathbb{I}_{D_{t}}$, where

$$
\mathbb{I}_{D_{t}}=\frac{D\left(Z_{t}\right)}{E_{t}\left[D\left(Z_{t}\right)\right]}
$$

is the ratio of the realized over the expected damage. ${ }^{13}$

Proposition 4 The liability rule $\mu_{t} Z_{t}^{i} \mathbb{I}_{D_{t}}$ is first-best efficient, robust and yields payments proportional to realized climate damage.

Proof. By definition, $E_{s}\left[\mathbb{I}_{D_{t}}\right]=1$ for all $s \leq t$, so that expected payments are unchanged. Hence, from Proposition 1, the liability rule is first-best efficient. For the same reason, from Proposition 2, it is robust to misrepresentation and deviations. Furthermore, $\mu_{t} Z_{t}^{i} \mathbb{I}_{D_{t}}$ is indeed proportional to realized harm:

$$
\begin{aligned}
\mu_{t} Z_{t}^{i} \mathbb{I}_{D_{t}} & =\frac{d D_{t}}{d Z_{t}} Z_{t}^{i} \frac{D_{t}\left(Z_{t}\right)}{E_{t}\left[D\left(Z_{t}\right)\right]} \\
& =\frac{Z_{t}^{i}}{Z_{t}} \frac{\left(d D_{t} / d Z_{t}\right)}{E_{t}\left[D_{t}\left(Z_{t}\right) / Z_{t}\right]} D_{t}\left(Z_{t}\right)
\end{aligned}
$$

If the damage function, $D_{t}$, were linear, payments would exactly cover total damage and countries would pay in proportion to their emission contributions: $\mu_{t} Z_{t}^{i} \mathbb{I}_{D_{t}}=\frac{Z_{t}^{i}}{Z_{t}} D_{t}\left(Z_{t}\right)$. If the damage function is convex, total payments add up to more than the realized damage because first-best efficiency requires going beyond full liability. ${ }^{14}$

\footnotetext{
${ }^{12}$ Obviously, for incentives to exist, "actual notice" is also needed; i.e., countries must not only be aware of the fact that they are causing harm (constructive notice), but must also be informed that they will be considered liable for future climate damage.

${ }^{13}$ Expectation is assumed to be taken at the beginning of the period.

${ }^{14}$ The incompatibility between first-best efficiency and budget balance is well-known. See, e.g., Billette de Villemeur and Leroux (2011).
} 
Remark 5 Full liability constitutes a conservative policy where payments rely only on realized damage, and not even on some estimate of the marginal damage function. In Europe and in the U.S., the field of environmental damage estimation is already well developed.

\section{References}

[1] Calabresi, G., The Cost of Accidents: A Legal and Economic Analysis, New Haven, CN.: Yale University Press, 1970.

[2] Billette de Villemeur, E. and J. Leroux (2011) "Sharing the Cost of Global Warming", The Scandinavian Journal of Economics, 113(4), 758-783.

[3] Hammond, Peter J., (1981) "Ex-Ante and Ex-Post Welfare Optimality under Uncertainty", Economica, 48 (n.191),235-250.

[4] Kolstad, C. D., T.S. Ulen and G.V. Johnson (1990), "Ex Post Liability for Harm,vs. Ex Ante Safety Regulation: Substitutes of Complements?", American Economic Review, 80(4), 888-901.

[5] Shavell, S. (1984) "Liability for Harm Versus Regulation of Safety", Journal of Legal Studies, June 1984, 13, 357-374.

[6] Shavell, Steven, (2011), "Corrective taxation versus liability", American Economic Review, Papers and Proceedings, 101(3), 273-276. 